\title{
Michel Baron, Théâtre complet, t. II
}

\section{Monica Pavesio}

\section{(2) OpenEdition}

\section{Journals}

\section{Edizione digitale}

URL: https://journals.openedition.org/studifrancesi/21211

DOI: 10.4000/studifrancesi.21211

ISSN: 2421-5856

\section{Editore}

Rosenberg \& Sellier

\section{Edizione cartacea}

Data di pubblicazione: 1 décembre 2019

Paginazione: $570-571$

ISSN: 0039-2944

\section{Notizia bibliografica digitale}

Monica Pavesio, «Michel Baron, Théâtre complet, t. I|», Studi Francesi [Online], 189 (LXIII | III) | 2019,

online dal 01 mars 2020, consultato il 12 novembre 2021. URL: http://journals.openedition.org/ studifrancesi/21211; DOI: https://doi.org/10.4000/studifrancesi.21211

\section{Questo documento è stato generato automaticamente il 12 novembre 2021.}

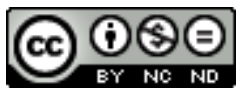

Studi Francesi è distribuita con Licenza Creative Commons Attribuzione - Non commerciale - Non opere derivate 4.0 Internazionale. 


\title{
Michel Baron, Théâtre complet, t. II
}

\author{
Monica Pavesio
}

\section{NOTIZIA}

Michel Baron, Théâtre complet, t. II, éd. I. Galleron et B. Sommovigo, Paris, Classiques Garnier, 2018, 445 pp.

1 A tre anni dal primo (M. Baron, Théâtre complet, Tome I, éd. I. Galleron et B. Sommovigo, Paris, Classiques Garnier, 2015, recensione di M. Pavesio in SF 181, 2017, p. 148) esce per le edizioni Garnier il secondo volume del Théâtre complet di Michel Baron, attore formatosi alla scuola di Molière e drammaturgo che compose le sue pièces tra la fine del Seicento e l'inizio del Settecento.

2 Le commedie contenute in questo secondo volume, Le Jaloux, L'Andrienne e L'Ecole des pères, rappresentate alla Comédie-Française alla fine del XVII secolo e nei primi anni del XVIII secolo, e pubblicate postume nel 1736, presentano un forte legame con le pièces di Molière e con le commedie di Terenzio. Baron, infatti, seppur autore di commedie, partecipò al movimento di riscoperta del teatro antico e della moralizzazione degli spettacoli, che prese avvio agli inizi del Settecento.

3 Le edizioni dei testi delle tre commedie sono a cura di B. Sommovigo, mentre le introduzioni sono opera di I. Galleron. Il volume contiene un glossario e gli indici dei nomi e delle opere. 